"Measuring the inclusiveness of international financing to tourism in Latin America and the Caribbean"

\begin{tabular}{|c|c|}
\hline AUTHORS & $\begin{array}{l}\text { Isabel Carrillo-Hidalgo (D https://orcid.org/0000-0002-0914-5084 } \\
\text { Juan Ignacio Pulido-Fernández (D http://orcid.org/0000-0002-9019-726X }\end{array}$ \\
\hline ARTICLE INFO & $\begin{array}{l}\text { Isabel Carrillo-Hidalgo and Juan Ignacio Pulido-Fernández (2018). Measuring } \\
\text { the inclusiveness of international financing to tourism in Latin America and the } \\
\text { Caribbean. Investment Management and Financial Innovations, 15(3), 15-34. } \\
\text { doi:10.21511/imfi.15(3).2018.02 }\end{array}$ \\
\hline DOI & http://dx.doi.org/10.21511/imfi.15(3).2018.02 \\
\hline RELEASED ON & Thursday, 05 July 2018 \\
\hline RECEIVED ON & Wednesday, 07 March 2018 \\
\hline ACCEPTED ON & Tuesday, 19 June 2018 \\
\hline LICENSE & $\begin{array}{l}(c) \text { EY-NC } \\
\text { This work is licensed under a Creative Commons Attribution-NonCommercial } 4.0 \\
\text { International License }\end{array}$ \\
\hline JOURNAL & "Investment Management and Financial Innovations" \\
\hline ISSN PRINT & $1810-4967$ \\
\hline ISSN ONLINE & $1812-9358$ \\
\hline PUBLISHER & LLC "Consulting Publishing Company "Business Perspectives" \\
\hline FOUNDER & LLC "Consulting Publishing Company "Business Perspectives" \\
\hline
\end{tabular}

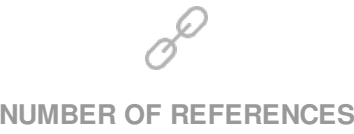

46

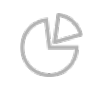

NUMBER OF FIGURES

5

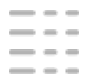

NUMBER OF TABLES

14

(C) The author(s) 2022. This publication is an open access article. 


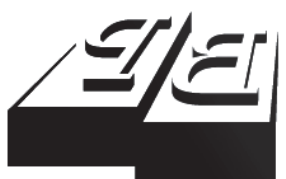

BUSINESS PERSPECTIVES

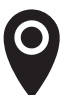

LLC "CPC "Business Perspectives" Hryhorii Skovoroda lane, 10, Sumy, 40022, Ukraine

www.businessperspectives.org

Received on: $7^{\text {th }}$ of March, 2018 Accepted on: $19^{\text {th }}$ of June, 2018

(C) Isabel Carrillo-Hidalgo, Juan Ignacio Pulido-Fernández, 2018

Isabel Carrillo-Hidalgo, Assistant Professor, University of Jaén, Laboratory of Analysis and Innovation in Tourism, Spain

Juan Ignacio Pulido-Fernández, Associate Professor, University of Jaén, Laboratory of Analysis and Innovation in Tourism, Spain.

\section{(ㄷ)(1) $(9$}

This is an Open Access article, distributed under the terms of the Creative Commons Attribution-NonCommercial 4.0 International license, which permits re-use, distribution, and reproduction, provided the materials aren't used for commercial purposes and the original work is properly cited.

\title{
MEASURING THE INCLUSIVENESS OF INTERNATIONAL FINANCING TO TOURISM IN LATIN AMERICA AND THE CARIBBEAN
}

\begin{abstract}
Globally, tourism has been identified as a means of poverty reduction and development, and as a means of encouragement of females, minorities and small businesses to better engage in the mainstream of economic life. This paper examines whether the international and governmental financial support, grated by international financial institutions, is effectively achieving these aims in Latin America and the Caribbean. A series of indices are established in the paper that assess the extent to which such funding includes non-corporate enterprise while also considering the volume and nature of such funding. It is concluded that the goals of inclusiveness are not being met.
\end{abstract}

\section{Keywords}

JEL Classification

international financial institutions, tourism, development cooperation, financial inclusion, funding

\section{INTRODUCTION}

International financial institutions ${ }^{1}$ (IFIs) have recognized the impact that tourism can have on economic growth and development, particularly in countries that have few alternative sources of income and that are dependent on other sectors. This phenomenon is not only a social issue, but also a powerful activity with significant potential for economic growth on the global scale (Ashley et al., 2007; Hawkins \& Mann, 2007; Jafari, 1990; Markandya et al., 2003; Pulido et al., 2008; Sharpley \& Telfer, 2002).

For development to be sustainable and efficient, however, it should not be based solely on the growth of productivity and gross domestic product; development should also ensure that growth benefits everyone, improves quality of life and contributes to the advancement of human development (Chandrasekhar, 2007).

In fact, IFIs have anti-financial exclusion policies. Since the concept of financial inclusion arose, IFIs have incorporated their principles into their development policies (Carrillo-Hidalgo \& Pulido-Fernández, 2012).

However, debate continues regarding these issues. As indicated by Chandrasekhar (2007), several development banks that fund projects

1 In this paper, the term IFIs (Carrillo-Hidalgo \& Pulido-Fernández, 2012) refers to global and regional development banks established by countries in different regions of the world: the World Bank (WB), the International Finance Corporation (IFC), the Multilateral Investment Guarantee Agency (MIGA), the Inter-American Development Bank (IDB), the African Development Bank (AfDB), the Asian Development Bank (ADB) and the European Bank for Reconstruction and Development (EBRD). Along with the above, the Organization of American States (OAS) is also included. 
are neither commercially nor socially beneficial, which is the result of poor decisions that were affected by authority or corruption. This influence leads to the allocation of funding to the most solvent and liquid sectors and/or the powerful elite.

In numerous economies, particularly those in developing countries, the growth of the tourism sector has stagnated because of the difficulties faced by local tourism businesses, mainly SMEs, in accessing the funding needed to develop their business.

Considering the importance that IFIs attach to financial inclusion and assuming the potential for tourism in developing economies, the promotion of these two aspects could positively affect the economy, particularly if local SMEs' access to credit was improved. Although SMEs are among the most excluded sectors, they also represent the most influential market sector for regional tourism development.

Thus, this research focuses on financial inclusion in tourism as a means of development for emerging economies with a certain amount of tourism potential. The purpose of this paper is to create a tool, which measures these aspects and allows conclusions to be drawn from the results. Furthermore, in a purely constructive spirit, the efficiency of these organizations and their actions in favor of the tourism development objectives will be discussed.

The region encompassing Latin America and the Caribbean stands out for its significant potential for tourism development, for the number of developing countries in which IFIs operate, and for the work that IFIs perform in the region's tourism. Therefore, it seems appropriate to analyze the role played by IFIs in Latin America and the Caribbean in the funding of international tourism and to assess whether these funding operations are conducted from the perspective of financial inclusion.

\section{THEORETICAL FRAMEWORK}

Financial exclusion is a reality for different segments excluded of the population as SMEs, the poorest households or women. And there are different causes from social and economic factors that limit financial intermediation, through problems derived from the inefficiencies or deficiencies of banks, to regulations and institutional deficiencies that tend to distort the provision of banking services (Rojas-Suárez, 2006).

According to Global Findex, there are 1.7 billion of unbanked adults worldwide, $56 \%$ of them being women and half of unbanked adults come from the poorest $40 \%$ of households within their economy, $69 \%$ of the region's population have an account in a financial institution, about half of adults affirm having savings in a financial institution and indicate that they received a loan in the past years (Demirgüç-Kunt et al., 2018).

The Universal Financial Access goal is that by 2020 , adults, who currently aren't part of the for- mal financial system, are able to have access to a transaction account to store money, send and receive payments as the basic building block to manage their financial lives (WB, 2018).

Yunus (2007), as the promoter of financial inclusion and micro-financing, considers that to reach a real solution to poverty, it is needed that all those who wish to develop their entrepreneurial spirit are able to do it and access to financial services by the majority of the population is essential for the development of an economy.

In accordance with the Organization for Economic Co-operation and Development (OECD) and the International network of Financial Education (OECD/INFE, 2012), financial inclusion consists of the promotion of affordable, timely and adequate access to the official financial system, as well as the expansion of its use by all segments of society through the implementation of personalized and innovative actions that include education and financial knowledge in order to promote well-being, and economic and social inclusion. It is a tool that promotes the generation of op- 
portunities that strengthen the ability to achieve the Sustainable Development Goals (Argumedo, 2017).

Scientific evidence indicates that fostering financial inclusion has positive effects at the micro and macro levels (Cull et al., 2014; Čihák et al., 2015; Demirgüç-Kunt et al., 2015; Mehrotra \& Yetman, 2015; Roa, 2014).

In view of this, the financial inclusion strategy should focus on developing: financial products adapted to the population with fewer resources; the design and dissemination of relevant and understandable information that will help combat distrust, improve decision making and generate products that meet the needs and restrictions of potential users, and the construction of a legal framework which is adequate for the development of financial infrastructure, so that the financial inclusion strategy does not threaten the stability of the financial system (Argumedo, 2017).

There are population sectors, which, due to their own characteristics, are more excluded from the formal financial system. At the business level, the size of companies and their technological capacity are the most critical variables to access financing, because these factors generate competitive advantages over financial markets (Botello, 2015). Credit is the main source of financing for SMEs, followed by credit from suppliers, leasing and factoring (Zuleta \& Alberto, 2016).

When it comes to tourism, in developing countries, this activity is stagnated due to the particular characteristics of the financing demand, requiring long-term financing and high amounts, mainly in the hotel and infrastructure sector, which makes their obtaining even more difficult. Thus, it is difficult and not homogenous for local tourism businesses, mainly SMEs, to access to the financing needed for the development of their business (Carrillo-Hidalgo \& Pulido-Fernández, 2016).

The scientific literature related to the financing of tourism by different OFIs is scarce. The existing studies (Markandya et al., 2003; Perric et al., 2011; Tapia, 2014) approach the subject from a descriptive perspective, but not from a critical point of view and evaluation of its activity.
Regarding the geographic scope of this research work, the Latin American and Caribbean financial system has a large number of gaps. Throughout its history, it has made great efforts to eliminate them and has faced various financial crises that have undermined its economic and financial stability, but its overcoming led to the strengthening of its financial systems, differing in degree, according to the countries. Advances were produced by improvements in the practices of banking regulation and supervision, as well as advances in measurement procedures and risk assessment in a lot of banks. But even so, it can be said that Latin America and the Caribbean have some financial systems with certain deficiencies that limit the full development of their economies (FELABAN, 2016)

Talking about data, in Latin America and the Caribbean, financial penetration at the regional level (calculated as ratio of credit or deposits to total GDP) is approximately $45 \%$, financing for small and medium enterprises accounts for $9 \%$ of the total regional portfolio, and added to the financing for microenterprise, totals $13 \%$, the amount of microcredits as a proportion of the commercial portfolio is below $10 \%$ and only $22.5 \%$ of investments in Latin America and the Caribbean are financed by loans. Next to the $30 \%$ of firms in this region identify access to finance as a mayor constraint (Trujillo \& Navajas, 2005; Enterprise Surveys, 2018).

The development banks operating in Latin America and the Caribbean have in common their public nature and the mission to contribute to the financing and development of the business sector using different instruments, breaking market failures and to promote financial inclusion (Zuleta \& Alberto, 2016). However, it is necessary to analyze in an objective way if those that are international in nature fulfill this function.

\section{METHODOLOGICAL APPROACH}

The tool was created through a prior review of the literature. To validate the tool, a panel of international experts in the field of tourism, funding and financial inclusion was consulted. Throughout the selection process, it was ensured that the group was sufficiently large and diverse to guarantee re- 
Table 1. Survey fact sheet

Source: Authors' own elaboration.

\begin{tabular}{|c|c|}
\hline Scope & $\begin{array}{l}\text { International professionals and experts in the field of international tourism funding and financial } \\
\text { inclusion }\end{array}$ \\
\hline Sample size & 48 \\
\hline Response rate & $22(45.8 \%)$ \\
\hline Profile of the respondents & $\begin{array}{l}\text { Profession: experienced researchers }(18.2 \%) \text {, professional workers of the OFIs }(50 \%) \text {, professional } \\
\text { workers of international tourism organizations }(4.6 \%) \text { and financial consultants }(27.3 \%) \text {. } \\
\text { Country location: France }(4.6 \%) \text {, Germany }(4.6 \%) \text {, New Zealand }(9.1 \%) \text {, Mexico }(9.1 \%) \text {, Spain } \\
(22.7 \%) \text {, Paraguay }(4.6 \%) \text {, Peru }(9.1 \%) \text {, United Kingdom }(4.6 \%) \text { and USA }(36.4 \%)\end{array}$ \\
\hline Research time period & $\begin{array}{l}\text { Beginning: January 10, } 2013 \\
\text { End: April } 18,2013\end{array}$ \\
\hline Type of study & Structured evaluation sheet sent by email \\
\hline
\end{tabular}

liable results and that diverse opinions would be considered, based on their individual experience and knowledge. Table 1 contains the fact sheet regarding the survey.

The survey was structured as an evaluation sheet of the different indicators that comprise the tool. For each indicator, a number of features were considered for evaluation (Table 2) after being identified in a thorough review of the specialized literature (AENOR, 2003; Ledgerwood, 1999; Roche, 2004; Xinia, 1995, among others). These evaluations were completed later by conducting a pre-test with a small group of experts involved in the process. In particular, the indicators known as SMART or SPICED were those which most inspired the definition of the qualities to be measured.

Respondents were asked to rate each of these features for each one of the indicators. To this end, nominal non-metric scales were used to identify the categories or options with which the respondent's opinion was identified, since these features are qualitative variables lacking quantitative significance. The study used a Likert scale to measure attitudes (scored from 1 to 5 ) and an interval scale (from 1 to 5 , from lowest to highest).

To determine the significance of the results obtained, the coefficient of internal consistency Cronbach's Alpha of the questions considered in each of the blocks was obtained. In addition, results comparisons were performed using multivariate statistical tests to the standardized values with the statistic Pillai test.

Latin America and the Caribbean, the geographical area in which the system of indicators was applied, was selected for four main reasons:
1) the difficulty of performing the study at a global level as a result of the volume of information that this would require, and the difficulty of gathering disaggregated information for all the projects that would have to be analyzed;

2) tourism is an activity that plays a key role in Latin America and the Caribbean;

3) the financial system in Latin America and the Caribbean has numerous gaps that impede access to the funding of excluded sectors, particularly SMEs;

4) this region has been the second most relevant in terms of funding provided by IFIs throughout the history of these organizations as financial backers of tourism.

The database used for this analysis consists of a total of 293 projects with influence on tourism financed by IFIs in Latin America and the Caribbean since the 1990s.

The period studied begins in 1990, the first year of a decade in which the concept of financial inclusion arose. Notably, it was not until then that the development potential offered by access to funding for all began to be considered. For this reason, information from $22 \mathrm{WB}$ projects financed before 1990 was not used to preserve the homogeneity of the database.

The study ends in 2012, the final year for which homogenous data are available for all of the organizations analysed, since updated information for the years 2013-2018 for all of the organizations was not then available. Based on the figures now available, it can be deduced that, on the one hand, little funding has been granted to tourism in the 
past three years, and on the other hand, that the tendency and behavior of the main characteristics identified and analyzed over the research period have remained constant. This time horizon is a sufficiently long period to analyze structural behavior through the funding granted by these organizations.

In the case of the OAS, the database is small because of the limited amount of information available. Detailed information regarding OAS funding for this type of project in LAC is only available from 2003 onwards. For this reason, the projects funded during this period (30 projects) have not been included in the calculation of certain indicators, because they require data that cannot be obtained.

After the tool to measure IFIs' endeavors for financial inclusion in tourism funding was developed and validated by the panel of experts, properly interpreted results were obtained. However, given the heterogeneity of the different indicators, and to draw conclusions from a more global, standardized perspective, the standardization of the data was necessary.

The results for each IFI for each indicator of the tool $\left(X_{i j}\right)_{2}$ were obtained, and the results were then normalized and standardized. A $Z_{i j}$ value was then calculated, which followed a normal distribution with a mean equal to 0 and a standard deviation equal to $1(\mathrm{~N}(0.1))$, thereby obtaining relative values that reflect the number of times a value is higher (values above zero) or lower (values below zero) than the mean. For this purpose, the following formula was applied:

$$
Z_{i j}=\frac{X_{i j}-\mu_{j}}{\sigma_{j}} .
$$

\section{PROPOSED TOOL FOR MEASURING FINANCIAL INCLUSION}

The tool developed to examine the level of financial inclusion in the projects related to tourism that are funded by these organizations consists of thirty-nine performance indicators, which measure and assess the financial performance of IFIs.

These indicators are divided into five different groups, depending on the aspects to be measured. To understand the results, the indicators were classified into two categories, considering the impact of the indicator on the end result:

"positive" indicators: those in which the higher the indicator value, the more favorable the attitude towards the promotion of financial inclusion shown by IFIs in the funding of tourism;

- "negative" indicators: those in which the lower the value of the indicator, the more favorable the attitude towards the promotion of financial inclusion shown by IFIs in the funding of tourism.

Thus, each indicator belongs to a specific group depending on the performance to be measured and is considered "positive" or "negative" depending on its category.

The development of indicators was based on a previous review of literature specifically dealing with the measurement of the level of financial inclusion of the activities of financial and regional institutions.

\subsection{Indicators of the financial inclusion level in the projects' development objectives}

This group of indicators (Table 2) helps to determine the extent to which IFIs incorporate the objective of financial inclusion into tourism development projects from a general perspective and from the specific perspective of women and SMEs (the groups that suffer most from financial exclusion).

The more this objective is considered in the financed projects, the better the performance shown regarding the fight against financial exclusion. For this reason, the three indicators of this section are considered as "positive".

2 Each organization being "i" and each indicator of the tool being “ $\mathrm{j}$ ”. 
Table 2. Indicators of the level of financial inclusion in the development objectives of the projects

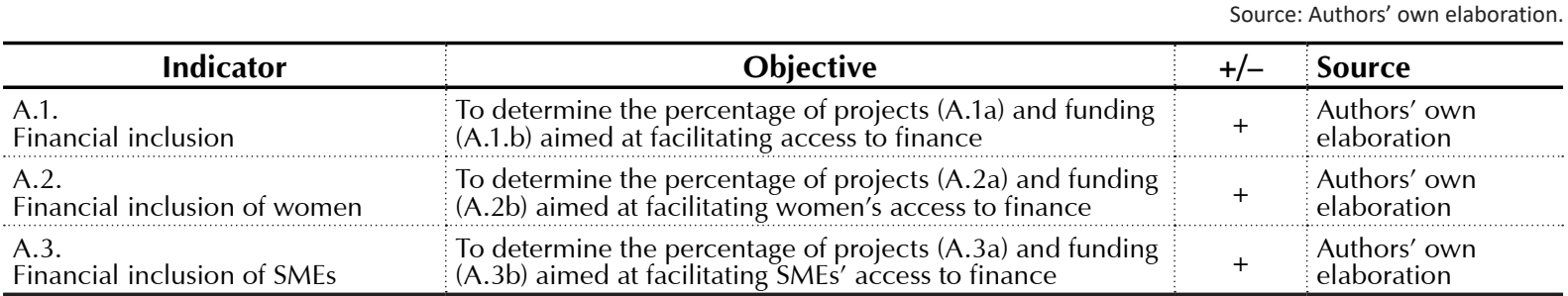

Note: Cronbach's Alpha: 0.61.

\subsection{Indicators of the scope and growth of the portfolio of recipients and end beneficiaries of funding}

These indicators (Table 3) examine the portfolio of clients and end beneficiaries of the funding. On the one hand, given the significance of women and SMEs in financial inclusion and the resulting beneficial effect on the entire population, the percentage of SMEs and women within the portfolio receiving funding is analyzed.

On the other hand, it is generally accepted that the public sector plays an important role in impro- ving access to finance and influencing legislation and regulations in the financial infrastructure of a country. It is of interest, therefore, to ascertain the percentage of funding for tourism allocated to the public sector. This aspect is examined through indicator B6, which is considered "negative", since it reflects the percentage of the public recipients of funding.

The use of an index developed by Rosenberg (2009), in this case, the indicator $\mathrm{B} 9$, makes it possible to determine the poverty level of clients.

Thus, the evolution and composition of the portfolio of clients and beneficiaries of these institutions are studied in this group of indicators.

Table 3. Indicators of the scope and growth of the portfolio of clients and end beneficiaries of the funding

\begin{tabular}{|c|c|c|c|c|c|c|c|}
\hline Indicator & Objective & $+/-$ & Source & Indicator & Objective & $+/-$ & Source \\
\hline $\begin{array}{l}\text { B1. } \\
\text { Number of } \\
\text { recipients of } \\
\text { funding }\end{array}$ & $\begin{array}{l}\text { To measure the } \\
\text { scope of the } \\
\text { loan portfolio }\end{array}$ & + & $\begin{array}{l}\text { Waterfield } \\
\text { and } \\
\text { Ramsing } \\
(1998)\end{array}$ & $\begin{array}{l}\text { B6. } \\
\text { Percentage of } \\
\text { public recipients }\end{array}$ & $\begin{array}{l}\text { To measure the public } \\
\text { sector share of the total } \\
\text { portfolio of recipients }\end{array}$ & - & $\begin{array}{l}\text { Authors' own } \\
\text { elaboration }\end{array}$ \\
\hline $\begin{array}{l}\text { B2. } \\
\text { Percentage of } \\
\text { women receiving } \\
\text { funding }\end{array}$ & $\begin{array}{l}\text { To measure } \\
\text { women's share } \\
\text { of the total } \\
\text { portfolio of } \\
\text { recipients }\end{array}$ & + & $\begin{array}{l}\text { Waterfield } \\
\text { and } \\
\text { Ramsing } \\
(1998)\end{array}$ & $\begin{array}{l}\text { B7. } \\
\text { Annual rate } \\
\text { of change in } \\
\text { the number of } \\
\text { recipients }\end{array}$ & $\begin{array}{l}\text { To measure the average } \\
\text { year-on-year rate of } \\
\text { change of the portfolio } \\
\text { of recipients of the total } \\
\text { tourism development } \\
\text { projects financed }\end{array}$ & + & $\begin{array}{l}\text { Waterfield } \\
\text { and Ramsing } \\
(1998)\end{array}$ \\
\hline $\begin{array}{l}\text { B3. } \\
\text { Percentage of } \\
\text { SMEs receiving } \\
\text { funding }\end{array}$ & $\begin{array}{l}\text { To measure } \\
\text { SMEs' share } \\
\text { of the total } \\
\text { portfolio of } \\
\text { recipients }\end{array}$ & + & $\begin{array}{l}\text { Sinha } \\
(2006)\end{array}$ & $\begin{array}{l}\text { B8. } \\
\text { Rate of growth } \\
\text { in the number of } \\
\text { recipients }\end{array}$ & $\begin{array}{l}\text { To measure the growth of } \\
\text { the portfolio of recipients } \\
\text { of the total tourism } \\
\text { development projects } \\
\text { funded throughout the } \\
\text { funding period of the } \\
\text { tourism activity studied }\end{array}$ & + & Ray (2002) \\
\hline $\begin{array}{l}\text { B4. } \\
\text { Percentage of } \\
\text { projects whose } \\
\text { end beneficiaries } \\
\text { are enterprises }\end{array}$ & $\begin{array}{l}\text { To measure the } \\
\text { share of projects } \\
\text { whose end } \\
\text { beneficiaries } \\
\text { are private } \\
\text { enterprises }\end{array}$ & + & $\begin{array}{l}\text { Authors' } \\
\text { own } \\
\text { elaboration }\end{array}$ & $\begin{array}{l}\text { B9. } \\
\text { Poverty level of } \\
\text { clients }\end{array}$ & $\begin{array}{l}\text { To compare the funding } \\
\text { allocated per client to the } \\
\text { weighted regional average } \\
\text { of the average GDP per } \\
\text { capita of the period } \\
\text { studied, thus determining } \\
\text { the poverty level }\end{array}$ & - & $\begin{array}{l}\text { Rosenberg } \\
(2009)\end{array}$ \\
\hline $\begin{array}{l}\text { B5. } \\
\text { Percentage of } \\
\text { projects whose } \\
\text { end beneficiaries } \\
\text { are SMEs }\end{array}$ & $\begin{array}{l}\text { To measure the } \\
\text { share of projects } \\
\text { whose end } \\
\text { beneficiaries are } \\
\text { SMEs }\end{array}$ & + & $\begin{array}{l}\text { Authors' } \\
\text { own } \\
\text { elaboration }\end{array}$ & $\begin{array}{l}\text { B10. } \\
\text { Drop-out rate }\end{array}$ & $\begin{array}{l}\text { To measure the average } \\
\text { percentage of recipients } \\
\text { ending their relationship } \\
\text { with an organization every } \\
\text { year }\end{array}$ & - & CERISE (2011) \\
\hline
\end{tabular}

Note: Cronbach's Alpha: 0.63 . 


\subsection{Indicators of aspects related to the volume of funding}

With regard to the volume of funding (Table 4), general indicators have been included. These indicators measure the average funding per project and recipient and the average number of projects funded for each of them, noting the sectors of the population suffering the most significant exclusion from the financial system (women and SMEs) and the evolution of the total amount of funding.

Regarding the funding allocated to the public sector, the study not only examined the percentage of funding allocated (indicator C7, which is negative for the same reasons already discussed for indicator B6), but also determined the share of projects implemented by the public sector aimed at promoting access to the financial sector (indicator C8).
Finally, regarding the volume of financing, the average year-on-year rate of change and its evolution are also analyzed, as is the growth rate of the amount of financing allocated to tourism development projects over the time horizon considered.

\subsection{Indicators of the characteristics of the funding}

This category (Table 5) includes a set of 11 indicators to examine the terms under which funding has been allocated and the type of financial instrument used. It also contains an index to study the level of dispersion of the financing allocated (Herfindahl-Hirschman Index).

We examine the average cost of the financing, the average time of approval (to measure the waiting time for its allocation), the maturity of the finan-

Table 4. Indicators of aspects related to the volume of funding

Source: Authors' own elaboration.

\begin{tabular}{|c|c|c|c|c|c|c|c|}
\hline Indicator & Objective & $+/-$ & Source & Indicator & Objective & $+/-$ & Source \\
\hline $\begin{array}{l}\text { C1. } \\
\text { Average amount } \\
\text { funded per recipient }\end{array}$ & $\begin{array}{l}\text { To calculate the } \\
\text { average amount } \\
\text { funded per recipient }\end{array}$ & - & $\begin{array}{l}\text { Stein, } \\
\text { Randhawa, } \\
\text { and } \\
\text { Bilandizic } \\
(2011)\end{array}$ & $\begin{array}{l}\text { C8. } \\
\text { Percentage of } \\
\text { funding allocated } \\
\text { to the public sector } \\
\text { aimed at improving } \\
\text { financial inclusion }\end{array}$ & $\begin{array}{l}\text { To determine the } \\
\text { percentage the } \\
\text { total amount of } \\
\text { funding allocated } \\
\text { to the public sector } \\
\text { aimed at improving } \\
\text { financial inclusion }\end{array}$ & - & $\begin{array}{l}\text { Authors' } \\
\text { own } \\
\text { elaboration }\end{array}$ \\
\hline $\begin{array}{l}\mathrm{C} 2 \text {. } \\
\text { Average size of the } \\
\text { projects }\end{array}$ & $\begin{array}{l}\text { To calculate the } \\
\text { average amount } \\
\text { funded per project }\end{array}$ & - & $\begin{array}{l}\text { CERISE } \\
(2011)\end{array}$ & $\begin{array}{l}\text { C9. } \\
\text { Average number } \\
\text { of projects funded } \\
\text { per recipient }\end{array}$ & $\begin{array}{l}\text { To determine the } \\
\text { number of projects } \\
\text { that have been } \\
\text { funded on average } \\
\text { per recipient }\end{array}$ & + & MIX (2011) \\
\hline $\begin{array}{l}\text { C3. } \\
\text { Average size of first } \\
\text { projects }\end{array}$ & $\begin{array}{l}\text { To measure the } \\
\text { average size of the } \\
\text { projects allocated to } \\
\text { new recipients }\end{array}$ & - & $\begin{array}{l}\text { Waterfield } \\
\text { and Ramsing } \\
\text { (1998) }\end{array}$ & $\begin{array}{l}\text { C10. } \\
\text { Average number of } \\
\text { projects allocated } \\
\text { to women }\end{array}$ & $\begin{array}{l}\text { To determine the } \\
\text { number of projects } \\
\text { that have been } \\
\text { funded, on average, } \\
\text { per woman }\end{array}$ & + & $\begin{array}{l}\text { Authors' } \\
\text { own } \\
\text { elaboration }\end{array}$ \\
\hline $\begin{array}{l}\text { C4. } \\
\text { Percentage of } \\
\text { financing allocated } \\
\text { to women }\end{array}$ & $\begin{array}{l}\text { To determine the } \\
\text { percentage of the total } \\
\text { amount of funding that } \\
\text { has been allocated to } \\
\text { women }\end{array}$ & + & Sinha (2006) & $\begin{array}{l}\text { C11. } \\
\text { Average number of } \\
\text { projects allocated } \\
\text { to SMEs }\end{array}$ & $\begin{array}{l}\text { To determine the } \\
\text { number of projects } \\
\text { that have been } \\
\text { funded, on average, } \\
\text { per SME }\end{array}$ & - & $\begin{array}{l}\text { Authors' } \\
\text { own } \\
\text { elaboration }\end{array}$ \\
\hline $\begin{array}{l}\text { C5. } \\
\text { Percentage of } \\
\text { funding allocated to } \\
\text { SMEs }\end{array}$ & $\begin{array}{l}\text { To determine the } \\
\text { percentage of the total } \\
\text { amount of funding that } \\
\text { has been allocated to } \\
\text { SMEs }\end{array}$ & + & $\begin{array}{l}\text { CERISE } \\
(2011)\end{array}$ & $\begin{array}{l}\text { C12. } \\
\text { Average year-on- } \\
\text { year rate of change } \\
\text { of the total amount } \\
\text { funded }\end{array}$ & $\begin{array}{l}\text { To measure the } \\
\text { average year-on- } \\
\text { year growth rate } \\
\text { of the funding } \\
\text { portfolio }\end{array}$ & & $\begin{array}{l}\text { Waterfield } \\
\text { and } \\
\text { Ramsing } \\
(1998)\end{array}$ \\
\hline $\begin{array}{l}\text { C6. } \\
\text { Percentage funded } \\
\text { in rural or isolated } \\
\text { areas }\end{array}$ & $\begin{array}{l}\text { To determine the } \\
\text { percentage of the total } \\
\text { amount of funding that } \\
\text { has been allocated to } \\
\text { rural or isolated areas }\end{array}$ & + & $\begin{array}{l}\text { Authors' own } \\
\text { elaboration }\end{array}$ & $\begin{array}{l}\text { C13. } \\
\text { Growth rate of the } \\
\text { funding portfolio }\end{array}$ & $\begin{array}{l}\text { To measure the } \\
\text { growth of the } \\
\text { funding portfolio } \\
\text { of tourism } \\
\text { development } \\
\text { projects throughout } \\
\text { the whole tourism } \\
\text { funding period }\end{array}$ & & Ray (2002) \\
\hline $\begin{array}{l}\text { C7. } \\
\text { Percentage of } \\
\text { funding allocated to } \\
\text { the public sector }\end{array}$ & $\begin{array}{l}\text { To determine the } \\
\text { percentage of the total } \\
\text { amount of funding that } \\
\text { has been allocated to } \\
\text { the public sector }\end{array}$ & - & $\begin{array}{l}\text { Authors' own } \\
\text { elaboration }\end{array}$ & & & & \\
\hline
\end{tabular}

Note: Cronbach's Alpha: 0.71. 
Table 5. Indicators for the study of the characteristics of the funding

\begin{tabular}{|c|c|c|c|c|c|c|c|}
\hline & & & & & Sou & : Auth & rs' own elaborat \\
\hline Indicator & Objective & $+/-$ & Source & Indicator & Objective & $+/-$ & Source \\
\hline $\begin{array}{l}\text { D1. } \\
\text { Level of } \\
\text { dispersion of } \\
\text { the financing }\end{array}$ & $\begin{array}{l}\text { To determine the level of } \\
\text { dispersion/concentration } \\
\text { of the funding }\end{array}$ & - & $\begin{array}{l}\text { Hirschman } \\
(1964)\end{array}$ & $\begin{array}{l}\text { D7. } \\
\text { Small financial } \\
\text { instruments }\end{array}$ & $\begin{array}{l}\text { To determine the } \\
\text { percentage of } \\
\text { funding allocated } \\
\text { through small loans }\end{array}$ & + & CERISE (2011) \\
\hline $\begin{array}{l}\text { D2. } \\
\text { Average } \\
\text { approval time }\end{array}$ & $\begin{array}{l}\text { To determine how long, } \\
\text { on average, organizations } \\
\text { take to approve a project } \\
\text { after it is evaluated }\end{array}$ & - & $\begin{array}{l}\text { CERISE } \\
(2011)\end{array}$ & $\begin{array}{l}\text { D.8 } \\
\text { Non- } \\
\text { reimbursable } \\
\text { funding }\end{array}$ & $\begin{array}{l}\text { To determine the } \\
\text { percentage of non- } \\
\text { reimbursable funding } \\
\text { allocated }\end{array}$ & + & $\begin{array}{l}\text { Authors' own } \\
\text { elaboration }\end{array}$ \\
\hline $\begin{array}{l}\text { D3. } \\
\text { Approximate } \\
\text { average } \\
\text { annual } \\
\text { effective cost }\end{array}$ & $\begin{array}{l}\text { To determine the } \\
\text { approximate average } \\
\text { effective cost of the } \\
\text { projects }\end{array}$ & - & $\begin{array}{l}\text { CERISE } \\
(2011)\end{array}$ & $\begin{array}{l}\text { D9. } \\
\text { Funding through } \\
\text { guarantees }\end{array}$ & $\begin{array}{l}\text { To determine the } \\
\text { percentage of } \\
\text { guarantees granted }\end{array}$ & + & $\begin{array}{l}\text { Authors' own } \\
\text { elaboration }\end{array}$ \\
\hline $\begin{array}{l}\text { D4. } \\
\text { Average } \\
\text { maturity }\end{array}$ & $\begin{array}{l}\text { To determine the } \\
\text { average maturity of the } \\
\text { reimbursable tourism } \\
\text { development projects } \\
\text { funded }\end{array}$ & + & $\begin{array}{l}\text { Authors' } \\
\text { own } \\
\text { elaboration }\end{array}$ & \begin{tabular}{l|} 
D10. \\
Funding \\
channelled \\
through other \\
financial entities
\end{tabular} & $\begin{array}{l}\text { To determine the } \\
\text { funding channelled } \\
\text { through other } \\
\text { financial entities }\end{array}$ & + & $\begin{array}{l}\text { Authors' own } \\
\text { elaboration }\end{array}$ \\
\hline $\begin{array}{l}\text { D5. Average } \\
\text { grace period }\end{array}$ & $\begin{array}{l}\text { To determine the average } \\
\text { grace period of the } \\
\text { tourism development } \\
\text { projects funded through } \\
\text { reimbursable funding }\end{array}$ & + & $\begin{array}{l}\text { Authors' } \\
\text { own } \\
\text { elaboration }\end{array}$ & $\begin{array}{l}\text { D11. } \\
\text { Sub-projects }\end{array}$ & $\begin{array}{l}\text { To determine the } \\
\text { number of projects } \\
\text { whose funding is } \\
\text { channelled to other } \\
\text { enterprises through } \\
\text { sub-projects }\end{array}$ & + & $\begin{array}{l}\text { Authors' own } \\
\text { elaboration }\end{array}$ \\
\hline $\begin{array}{l}\text { D6. } \\
\text { Emergency } \\
\text { financial } \\
\text { instruments }\end{array}$ & $\begin{array}{l}\text { To determine the } \\
\text { percentage of funding } \\
\text { allocated using } \\
\text { emergency loans }\end{array}$ & + & $\begin{array}{l}\text { Authors' } \\
\text { own } \\
\text { elaboration }\end{array}$ & & & & \\
\hline
\end{tabular}

Note: Cronbach's Alpha: 0.689.

cing (to determine whether it is short, medium or long-term financing and analyze its suitability for promoting financial inclusion) and the grace periods (which allow entrepreneurs to start their businesses without immediately repaying the amount allocated for financing).

In addition, a number of instruments that promote access to further financing are also examined.

\subsection{Indicators of non-financial support for inclusion}

The conditions under which funding is allocated are important, as are the facts that funding is allocated to those most in need and that the end beneficiaries are groups excluded from the financial system. However, another significant factor is the provision of non-financial support (Table 6) such that these funds produce the best possible results regarding financial inclusion.

Within non-financial services, technical assistance and training are the most effective. Thus, the provision of these services, which are focused on financial and business management, will increase the chances of success of the financing allocated.
Table 6. Indicators of non-financial support for inclusion

Source: Authors' own elaboration.

\begin{tabular}{|c|c|c|c|}
\hline Indicator & Objective & $+/-$ & Source \\
\hline $\begin{array}{l}\text { E1. } \\
\text { Technical } \\
\text { assistance } \\
\text { in financial } \\
\text { and business } \\
\text { management }\end{array}$ & $\begin{array}{l}\text { To determine the } \\
\text { percentage of projects } \\
\text { which, apart from funding, } \\
\text { have received technical } \\
\text { assistance in financial and } \\
\text { business management }\end{array}$ & + & $\begin{array}{l}\text { Authors' } \\
\text { own } \\
\text { elaboration }\end{array}$ \\
\hline $\begin{array}{l}\text { E2. } \\
\text { Training in } \\
\text { financial } \\
\text { and business } \\
\text { management }\end{array}$ & $\begin{array}{l}\text { The determine the } \\
\text { percentage of projects } \\
\text { which, apart from funding, } \\
\text { include staff training } \\
\text { activities related to financial } \\
\text { and business management }\end{array}$ & + & $\begin{array}{l}\text { Authors' } \\
\text { own } \\
\text { elaboration }\end{array}$ \\
\hline
\end{tabular}

Note: Cronbach's Alpha: 0.539.

In general terms, the tool has been validated by the panel of experts who provided their personal opinion in the evaluation based on wide-ranging knowledge and extensive experience in the field.

The indicators have provided a median situated between a minimum of four and a maximum of five, with an interquartile range (IQR) between 1 and 2 (mean of 1.6). This tool therefore significantly or fully meets the requirements of a good indicator. Notably, however, each of the indicators 
comprising the tool obtained different results and indicated different degrees of dispersion, with no indicator excluded after the evaluation.

Table 7 summarizes the average median and IQR values obtained from the evaluation of the indicators comprising each block.

Table 7. Evaluation of the financial inclusion measurement tool

Source: Authors' own elaboration.

\begin{tabular}{c|c:c}
\hline Indictors & Median & Interquartile range \\
\hline A & 4 & 1.6 \\
\hline B & 4 & 1.8 \\
\hline C & 4 & 1.6 \\
\hline D & 4 & 1.8 \\
\hline E & 4 & 1.6 \\
\hline
\end{tabular}

\section{RESULTS OF THE FINANCIAL INCLUSION MEASUREMENT TOOL}

By analyzing the work of IFIs in the field of financial inclusion through projects which affect the tourism sector in LAC, an overview can be obtained of the characteristics of the funding given to tourism in terms of financial inclusion. This overview indicates the importance attached to financial inclusion among the objectives of the projects funded, the scope and growth of the portfolio of the final recipients of the funding, the appropriateness of the volume and characteristics of the funding for the purpose of facilitating access to finance, and the non-financial endeavors made to combat financial exclusion.

\subsection{Level of immersion of financial inclusion in the development objectives of the projects}

Each of the projects funded by the IFIs has a series of objectives, which can be broken down into sub-objectives. Of the total volume of projects and funding by IFIs in the tourism sector in Latin America and the Caribbean, as indicated by A1.a and A1.b (Figure 1), less than 25\% aim to promote financial inclusion.

If the circle of financial inclusion is closed even further to examine the access of women and/or SMEs to credit, these percentages are much lower. Table 8 depicts the behavior of each organization in this respect.

Financiation with F.I. objective

Projects with F.I. objective

Projects with F.I. objective-women

Financiation with F.I. objective-women

Projects with F.I. objective-SMEs

Financiation with F.I. objective-SMEs

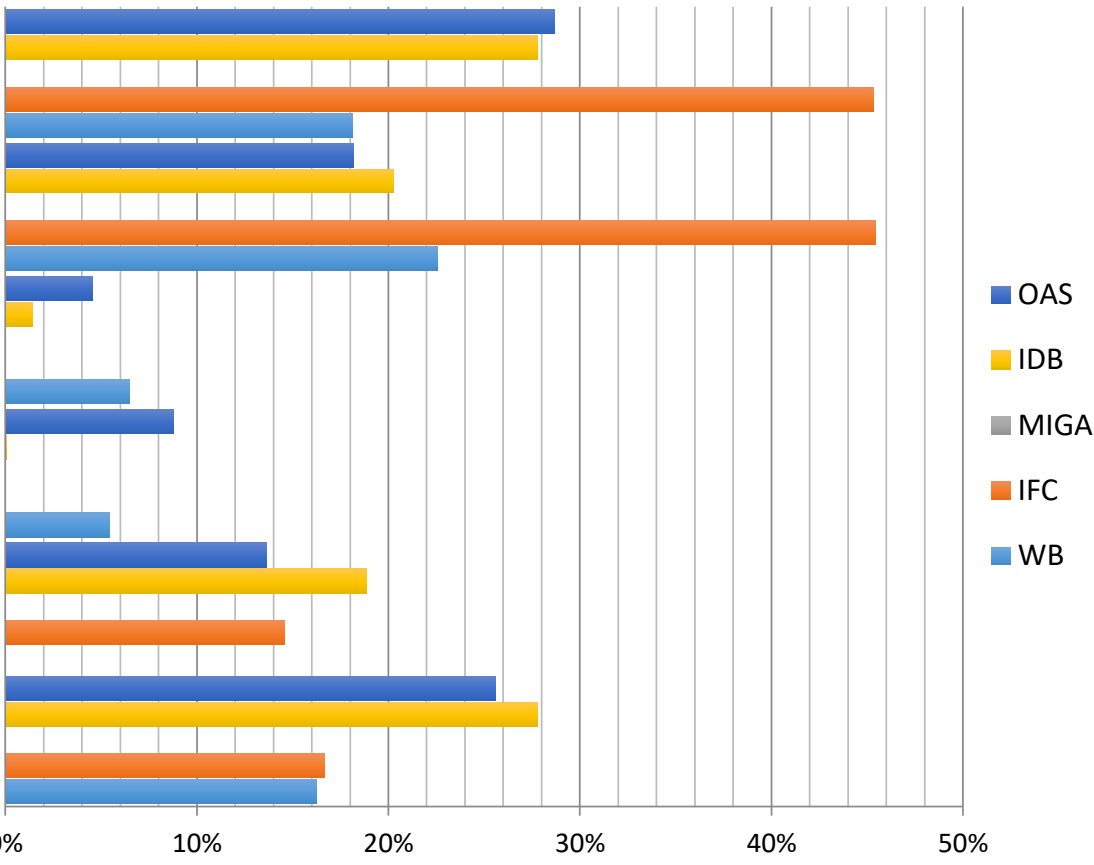

Figure 1. Indicators: Objective: Financial inclusion of women and SMEs, by organization 
Table 8. Indicators of the level of financial inclusion in the development objectives of the projects, results

Source: Authors' own elaboration from WB (2015), IFC (2015), MIGA (2015), IDB (2015) and OAS (2015).

\begin{tabular}{c|c|c|c|c|c|c}
\hline Indicator & WB & IFC & MIGA & IDB & OAS & TOTAL \\
\hline A1.a & $22.58 \%$ & $45.45 \%$ & $0.00 \%$ & $20.28 \%$ & $18.18 \%$ & $21.30 \%$ \\
A1.b & $18.15 \%$ & $45.33 \%$ & $0.00 \%$ & $27.78 \%$ & $28.66 \%$ & $23.98 \%$ \\
A2.a & $6.45 \%$ & $0.00 \%$ & $0.00 \%$ & $1.40 \%$ & $4.55 \%$ \\
A2.b & $5.41 \%$ & $0.00 \%$ & $0.00 \%$ & $0.09 \%$ & $8.77 \%$ & $2.48 \%$ \\
A3.a & $19.35 \%$ & $14.55 \%$ & $0.00 \%$ & $18.88 \%$ & $13.64 \%$ \\
A3.b & $16.23 \%$ & $16.66 \%$ & $0.00 \%$ & $27.77 \%$ & $25 \%$ \\
\hline
\end{tabular}

Note: Multivariate Pillai test for the standardized values 0.302 and $p$-value $<0.001$.

SMEs figure more highly than women in terms of their inclusion among the objectives of IFI-funded projects, which influence tourism. Indicator A3 (Table 8) suggests that $13.2 \%$ of the projects and $17.2 \%$ of the funding for tourism had the objective of combating the financial exclusion of SMEs.

None of the results of indicator A2 for any of the organizations exceeds $10 \%$. The only standout figure is that of the OAS, followed by the WB.

As indicated in the methodological approach, for each group of indicators (Tables 8 and 12), the multivariate Pillai for the standardized values has been obtained. It should be noted that in all of them there are significant differences in the multivariate test, which indicates that they are different evaluations depending on the factor (WB, IFC, MIGA, IDB, OAS), except in group $\mathrm{E}$, in which no differences are seen.

\subsection{Scope and growth of the portfolio of recipients and final beneficiaries of the funding}

In this block of indicators, the scope and characteristics of the recipients and final beneficiaries of the funding are analyzed by studying the composition and the evolution of the portfolio. The results are shown in Table 9.

Since 1990, IFIs have granted funding for projects, which influence tourism in LAC to a total of 155 different recipients (indicator B1). This represents an annual average of seven recipients, a figure which may be considered fairly low, bearing in mind the size of these organizations and the large volume of capital which they manage.

Indicators B2 and B3 suggest that in the portfolio of recipients of tourism-related IFI funding, women and SMEs each represent just $0.48 \%$ of the total. The weighting given to these groups is therefore minimal.

Of the five organizations studied, the only one that finances any specific project for SMEs and/or women is the IFC, although this is almost residual. In fact, of the total number of projects comprising the portfolio, only one is an SME and only one has been granted to women (2.38\%).

The data provided by these indicators suggest that the IFIs distribute funding for tourism primarily to the public sector and large enterprises. In fact, indicator B6 reflects the fact that, of the total number of recipients, $53.81 \%$ are public bodies or organizations. To promote financial inclusion, it is necessary to support governments, since they can achieve a significant impact by adopting specific measures in this regard (WB, 2008).

Indicator B4 (Table 9) indicates that $30.4 \%$ (Figure 2) of the final and indirect beneficiaries of tourism development projects are other private sector companies and entrepreneurs, not the initial recipient. The remaining $69.6 \%$ of the projects affect only the recipients themselves, which indicates a narrower reach of the funding granted.

Indicator B5 (Table 9) examines this question in greater depth. On average, 22.19\% (Figure 2) of the projects have final beneficiaries other than the initial recipient, including other private sector companies and SMEs.

Based on the proposal by Rosenberg (2009), indicator $\mathrm{B} 9$ provides information in two ways. When the value is less than $20 \%$, it reveals the level of poverty of the recipients of the funding; when the indicator shows a value not greater than $250 \%$, the volume of the funding provided is close to that of micro-fi- 


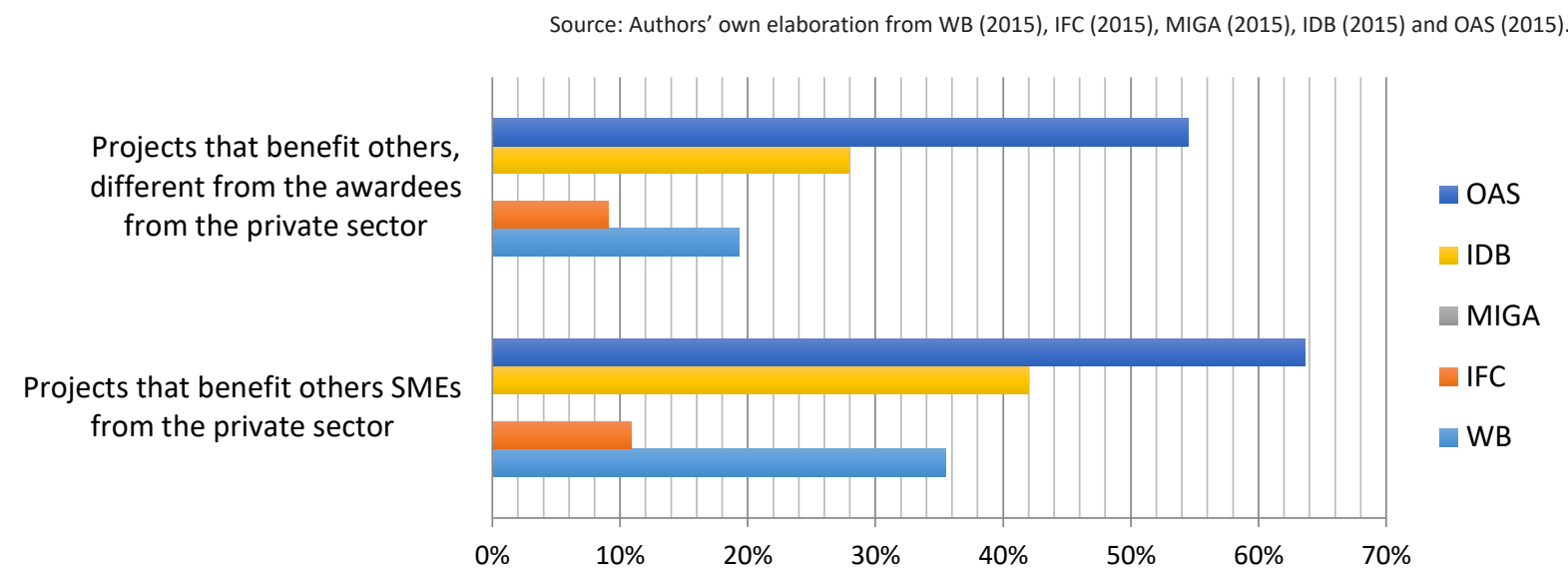

Figure 2. Projects whose final beneficiaries are other companies and SMEs, by organizations (indicators B4 and B5)

nancial institutions (whose method of work is better adapted to the fight against financial exclusion).

Regarding the funding of tourism in LAC by IFIs, indicator B9 gives a value of $27,803 \%$ (Table 9). This value is somewhat disproportionate; in fact, it allows us to state that in tourism, IFIs do not grant funding to poor people or in volumes likely to favor financial inclusion in LAC. The values obtained by the different organizations vary between 15.300 and $60,000 \%$, and thus the same conclusions are applicable. Only the OAS has a value for indicator B9 of $129 \%$, which means that the volume of its adjudications is in line with the requirements of the struggle against financial exclusion.
Finally, the evolution of the portfolio of recipients of these organizations is analyzed with respect to the funding of tourism in LAC. The mean year-onyear rate of variation in the IFI portfolio of recipients of funding for tourism shows an average value of $22 \%$. The evolution of this indicator (Figure 3) shows a general downward tendency, with periods in which there has been a sharp increase in the rate (the 1990s, when the concept of financial inclusion and sustainable tourism arose), reaching values of $150 \%$, and others (since the turn of the century) in which it has been lower, not having exceeded $11 \%$ over the past decade.

The total growth rate in the number of recipients since the IFIs began to provide funding for tou-

Source: Authors' own elaboration from WB (2015), IFC (2015), MIGA (2015), IDB (2015) and OAS (2015).

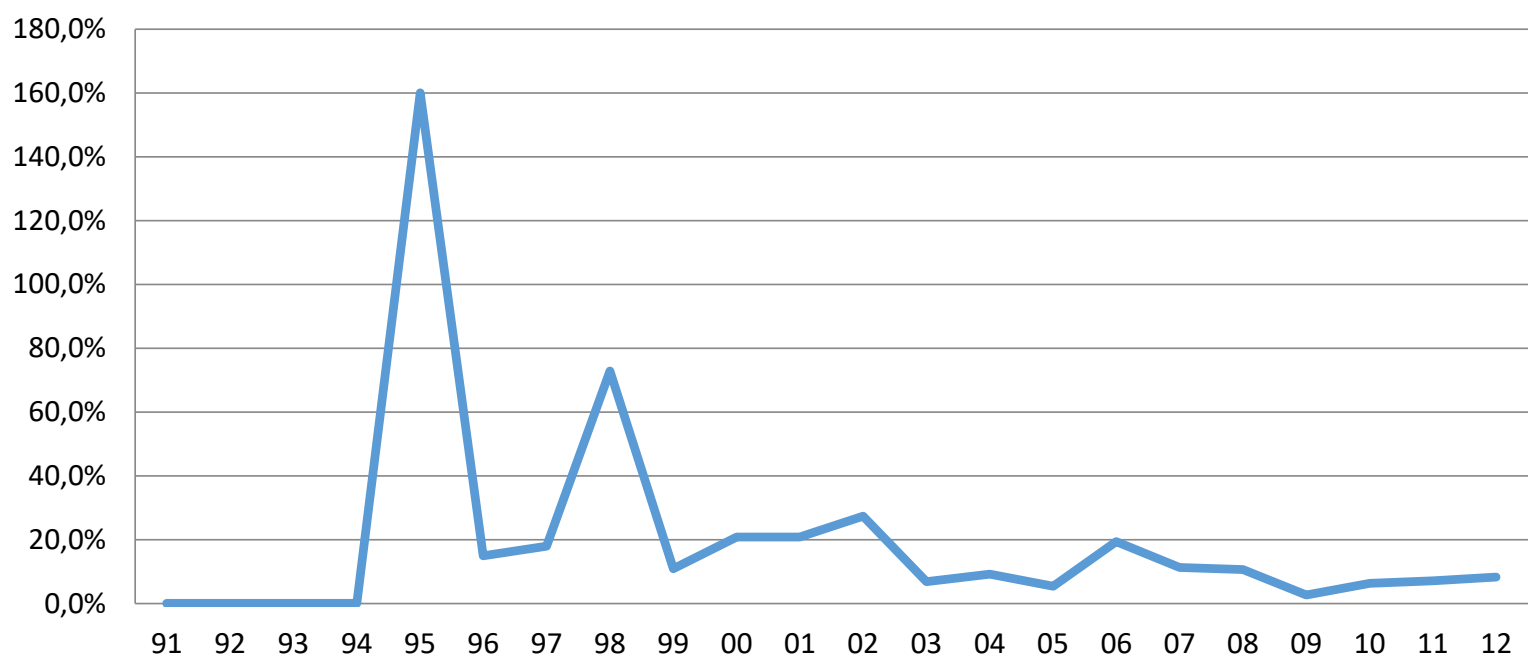

Figure 3. Evolution of the mean year-on-year rate of variation in the portfolio of recipients, indicator B7 (1991-2012) 
Table 9. Indicators of the scope and growth of the portfolio of clients and end beneficiaries of the funding, results

Source: Authors' own elaboration from WB (2015), IFC (2015), MIGA (2015), IDB (2015) and OAS (2015).

\begin{tabular}{|c|c|c|c|c|c|c|}
\hline Indicator & WB & IFC & MIGA & IDB & OAS & Total \\
\hline B1 & 26 & 42 & 6 & 63 & 18 & 155 \\
\hline B2 & $0,00 \%$ & $2.38 \%$ & $0.00 \%$ & $0.00 \%$ & $0.00 \%$ & $0.48 \%$ \\
\hline B3 & $0.00 \%$ & $2.38 \%$ & $0.00 \%$ & $0.00 \%$ & $0.00 \%$ & $0.48 \%$ \\
\hline B4 & $35.48 \%$ & $10.91 \%$ & $0.00 \%$ & $41.96 \%$ & $63.64 \%$ & $30.40 \%$ \\
\hline B5 & $19.35 \%$ & $9.09 \%$ & $0.00 \%$ & $27.97 \%$ & $54.55 \%$ & $22.19 \%$ \\
\hline B6 & $100.00 \%$ & $0.00 \%$ & $16.67 \%$ & $63.49 \%$ & $88.89 \%$ & $53.81 \%$ \\
\hline B7 & $18.48 \%$ & $25.99 \%$ & $6.11 \%$ & $42.52 \%$ & $17.69 \%$ & $22.16 \%$ \\
\hline B8 & $14.81 \%$ & $16.99 \%$ & $4.99 \%$ & $18.83 \%$ & $14.23 \%$ & $13.97 \%$ \\
\hline B9 & $38,517.10 \%$ & $25,038,24 \%$ & $60,055.96 \%$ & $15,276.95 \%$ & $129.49 \%$ & $27,803.55 \%$ \\
\hline B10 & $10.11 \%$ & - & - & $8.59 \%$ & $42.37 \%$ & $20.36 \%$ \\
\hline
\end{tabular}

Note: Multivariate Pillai test for the standardized values 0.404 and $p$-value $<0.001$.

rism in LAC and until 2012 has been on average 13.97\% (indicator B8, Table 9). This rate of change is lower than the year-on-year rate and denotes little effort to reach the highest possible number of people through the funding of tourism activities.

Indicator B10 (Table 9) reflects the capacity of these organizations to maintain a given number of recipients, measuring the number of dropouts among the recipients. The mean dropout rate of the portfolio of recipients of IFI funds for tourism projects in LAC was $20.36 \%$. Because this value is between $15 \%$ and $30 \%$, it is considered an average value based on the assessment of micro-funding institutions established by CERISE (2011).

\subsection{Volume of funding}

This third element of the tool analyzes the volume and the number of projects that receive tourism funding from the IFIs. Indicator C1 (Stein et al., 2011) determines the mean amount of funding for tourism activity awarded to each recipient by the IFIs. Since the 1990s, 155 recipients (indicator B1) in LAC received tourism-related funding from the IFIs of USD 44.9 million (Table 10). This figure is a very high if it is devoted to promoting financial inclusion, since large amounts of money have been concentrated in very few hands.

Indicators $\mathrm{C} 2$ and $\mathrm{C} 3$ indicate that the amount of funding per tourism development project in LAC has averaged USD 28 million and that the amount granted to the first project of this type was on average USD 31 million (Table 10).
Indicators $\mathrm{C} 4$ and $\mathrm{C} 5$ corroborate the information provided by indicators $\mathrm{B} 2$ and $\mathrm{B} 3$, indicating that only the IFC directly provides funding to women and SMEs in the tourism sector. As reflected in Table 10, the IFC adjudicated $0.12 \%$ of funding for tourism to women and $0.47 \%$ to SMEs. On average, women and SMEs received $0.02 \%$ and $0.09 \%$, respectively, of the total funding provided by the IFIs for the development of tourism in LAC (Table 10). These percentages are far from sufficient. Notably, four of the five organizations studied have not devoted any direct funds to these sectors in the field of tourism.

Indicator C6 provides information about the financial assistance offered in rural and excluded areas. In this case, the result is more positive (30.5\%), but this result is primarily linked to the WB (82\%). Indicators C7 and C8 complement the conclusions drawn from indicator B6 (percentage of public recipients) with respect to the funding for tourism provided to the public sector.

In summary, the results produced by indicators $\mathrm{C} 7$ and $\mathrm{C} 8$ show that, on average, the IFIs devoted nearly $70 \%$ of their tourism funding to the public sector. Nevertheless, it is unlikely that IFIs are achieving their financial inclusion objectives, since only $14.42 \%$ of funding is granted for this purpose to public bodies (Table 10), a proportion which is considered to be far from sufficient.

Offering consistent financial support and establishing a long-term relationship with the organization increases the capital at the disposal of the 
Table 10. Indicators of aspects related to the volume of funding, results

Source: Authors' own elaboration from WB (2015), IFC (2015), MIGA (2015), IDB (2015) and OAS (2015).

\begin{tabular}{|c|c|c|c|c|c|c|}
\hline Indicator & WB & IFC & MIGA & IDB & OAS & MEAN \\
\hline C1 & 62,21 & 40.44 & 97.00 & 24.67 & 0.21 & 44.90 \\
\hline $\mathrm{C} 2$ & 52.17 & 30.88 & 48.50 & 10.87 & 0.13 & 28.51 \\
\hline $\mathrm{C} 3$ & 47.35 & 31.87 & 67.57 & 11.72 & 0.19 & 31.74 \\
\hline $\mathrm{C} 4$ & $0.00 \%$ & $0.12 \%$ & $0.00 \%$ & $0.00 \%$ & $0.00 \%$ & $0.02 \%$ \\
\hline C5 & $0.00 \%$ & $0.47 \%$ & $0.00 \%$ & $0.00 \%$ & $0.00 \%$ & $0.09 \%$ \\
\hline $\mathrm{C} 6$ & $82.35 \%$ & $10.04 \%$ & $17.44 \%$ & $32.20 \%$ & $10.45 \%$ & $30.50 \%$ \\
\hline $\mathrm{C} 7$ & $100.00 \%$ & $0.00 \%$ & $54.99 \%$ & $94.09 \%$ & $96.41 \%$ & $69.10 \%$ \\
\hline $\mathrm{C} 8$ & $18.15 \%$ & $0.00 \%$ & $0.00 \%$ & $26.79 \%$ & $27.17 \%$ & $14.42 \%$ \\
\hline C9 & 1.19 & 1.31 & 2.00 & 2.27 & 1.22 & 1.60 \\
\hline C10 & 0.00 & 1.00 & 0.00 & 0.00 & 0.00 & 0.20 \\
\hline C11 & 0.00 & 1.00 & 0.00 & 0.00 & 0.00 & 0.20 \\
\hline $\mathrm{C} 12$ & $27.19 \%$ & $20.95 \%$ & $22.14 \%$ & $85.03 \%$ & $14.15 \%$ & $33.89 \%$ \\
\hline C13 & $19.87 \%$ & $16.02 \%$ & $14.84 \%$ & $32.39 \%$ & $32.20 \%$ & $23.07 \%$ \\
\hline
\end{tabular}

Note: Multivariate Pillai test for the standardized values 0.742 and $p$-value $<0.001$.

recipient, leading to improved development of business activity (MIX, 2011).

According to indicator $\mathrm{C} 9$, each recipient has received funding for an average of 1.60 tourism development projects, meaning that the majority of recipients have received funding for tourism-related activities in one or two projects. However, this repeated support is not provided to the neediest recipients who are excluded from the formal system, since IFIs primarily provide funding to the public sector rather than to private companies, which are excluded from the system; less than $22 \%$ (indicator A1) of funding is devoted to the fight against this type of exclusion.
As shown in Figure 4, the mean year-on-year variation in funding for tourism provided by IFIs is $33.89 \%$ (Table 10). This figure is not insignificant, except that this growth is not distributed uniformly over the years, but instead is concentrated in the second half of the 1990s, 2002 and 2011, years in which the rate of variation was more than $40 \%$ (Figure 4). The organization that prompted this mean tendency was the IDB, with rates as high as $1.000 \%$ in 1996.

The total growth rate in funding for tourism (indicator C13) from the beginning of the study until today shows a mean value of $23.02 \%$ (Table 10 ). This value results in a mean year-on-year rate that exceeds the overall rate.

Source: Authors' own elaboration from WB (2015), IFC (2015), MIGA (2015), IDB (2015) and OAS (2015).

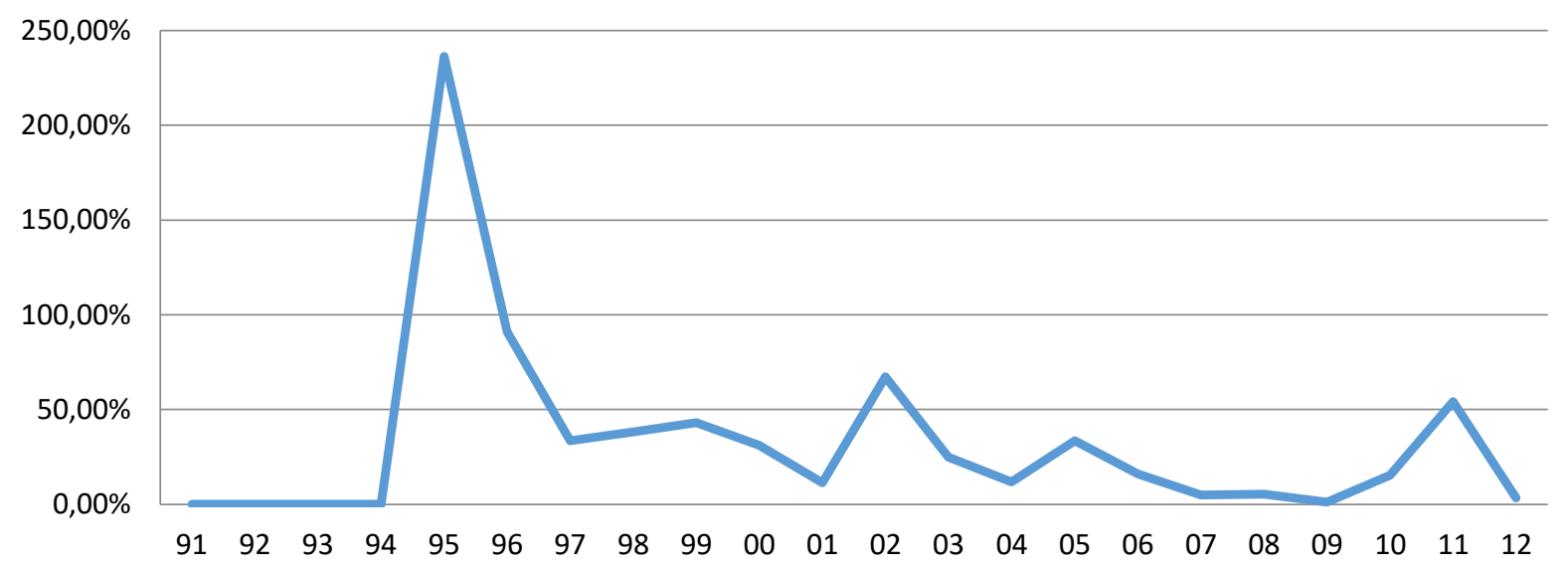

Figure 4. Indicator C12: Mean year-on-year rate of variation in the total amount of funding provided for tourism (2000-2012) 


\subsection{Characteristics of the funding}

Examining the procedure, characteristics and instruments of tourism funding is important in determining to what extent access to funding for those suffering the greatest exclusion from the formal system has been achieved. Block D of the tool's indicators provides this information.

This group of indicators begins with D1, also known as the Herfindahl-Hirschman Index (Hirschman 1964), whose original version has been used to evaluate the degree of concentration of financial institutions.

This indicator has been adapted to ascertain to what extent IFIs concentrate their tourism funding activities in LAC. The fact that the operations are concentrated in certain territories may lead to neglect in other areas in need of stronger financial support.

The behavior of an organization can be considered completely concentrated if it obtains a value of 1 in this indicator. The mean score of the IFIs for indicator D1 was 0.29 (Table 11), meaning that there is a certain degree of dispersion at the country level. The IFI with the most homogenous distribution of funding for tourism is the IFC, whose HerfindahlHirschman index was 0.14 .

Funding that promotes financial inclusion is that which is approved quickly with short, simple, and flexible bureaucratic procedures; in this way, the funding will be more accessible to those groups excluded from the formal financial system. Funds should also have a low interest rate, a long maturity date and grace periods that will allow funds to be repaid easily and fluidly. These funding conditions would encourage the opening of the system and would improve development for the recipients of the funding (CERISE, 2011; Demirgüç-Kunt \& Maksimovic, 1999).

Indicators D2, D3, D4 and D5 provide information regarding these characteristics of tourism-related funding granted by IFIs in LAC.

The average period for the approval of the tourism development projects funded by IFIs in LAC was nearly sixteen and a half months (Table 11). The information for this indicator was obtained from WB, IFC and IDB figures, due to the limited data available from the other organizations.

The IDB (2012) indicates that the mean bank interest rate in LAC countries has fluctuated between $10 \%$ and $32 \%$ since 2007 . Since the mid1990s, average annual interest rates have at no time, and in no LAC country, exceeded 6\%. From 1995 to 2012, the average interest rate in the region has fluctuated between $7.60 \%$ (El Salvador) and 43.82\% (Brazil) (CEPAL, 2007, 2008, 2009, 2010, and 2012). Therefore, the effective average cost of the tourism projects funded by IFIs is much lower than the normal market interest rate; according to Indicator $\mathrm{D} 3$, the effective average cost was $0.37 \%$ (Table 11).

IFIs are able to grant funding over a longer term, adapting the maturity dates to the needs of the recipients. As depicted in Table 11, funding for tourism is being granted in the very long term, averaging 20 years, thereby making a very positive contribution to the growth of the companies (Demirgüç-Kunt \& Maksimovic, 1999). This finding is particularly notable in the tourism sector, where the investment to be made is significantly high.

With regard to grace periods, a beneficial aspect of financial inclusion, information was only supplied by the WB and the IDB (Table 11). These periods are 90 and 60 months, respectively, which represents an average grace period of approximately six years.

The manner in which the funding reaches the development projects is also important. Indicators D6, D7, D8, D9, D10 and D11 (Figure 5) analyze the types and forms of financial instruments used by IFIs and examine which are considered favorable to financial inclusion.

Indicator D6 shows that only the $\mathrm{WB}$ and the IDB have used emergency funding in proportions lower than $10 \%$. This proportion is small considering the fact that numerous events have occurred during this period that have been classified as "difficult and unforeseeable", requiring the participation and financial support of these organizations. 


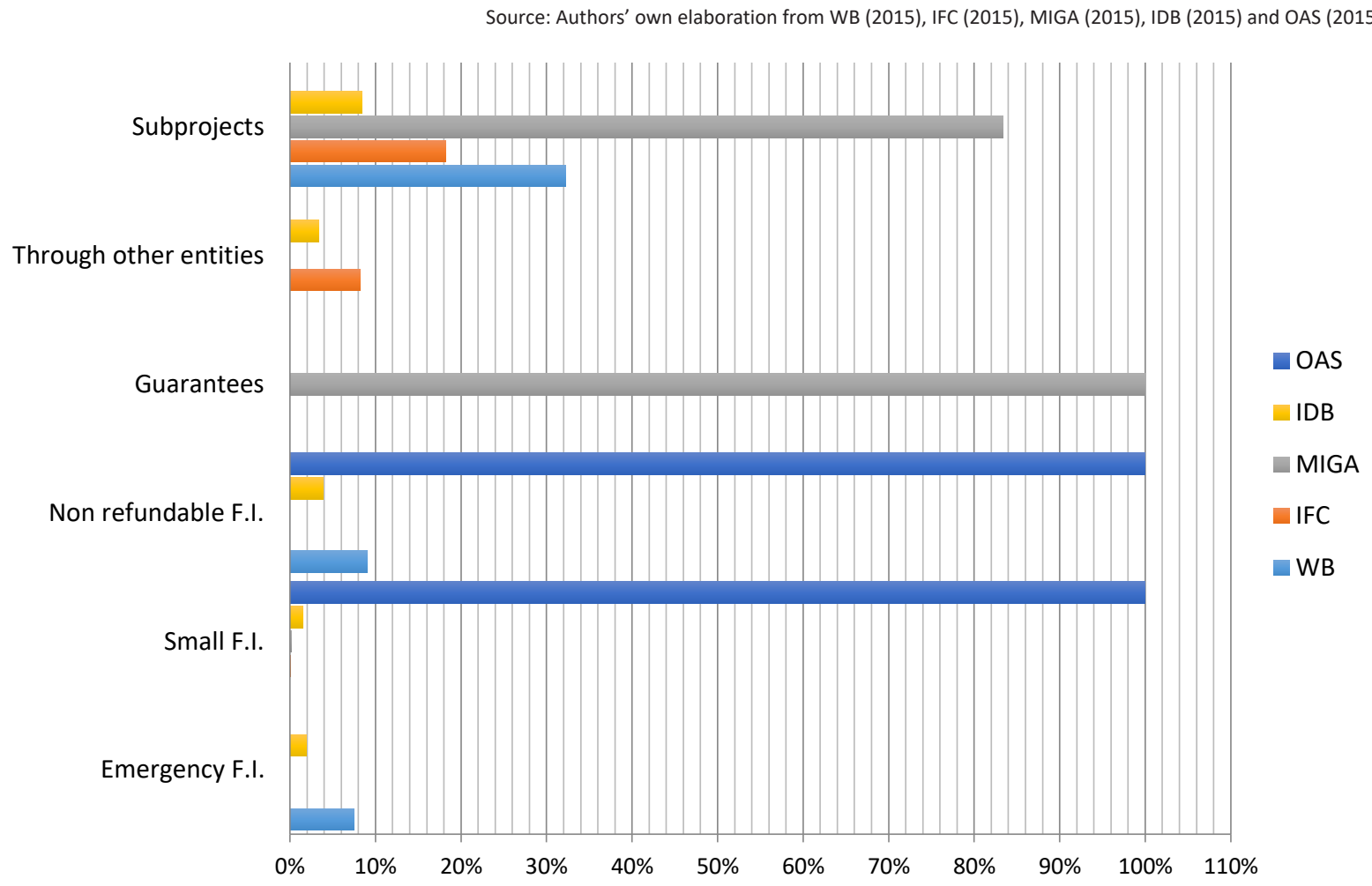

Figure 5. Indicators D6, D7, D8, D9, D10 and D11, financial instruments used by the IFIs for the funding of tourism, by organization

Indicator D7 reveals the proportion of funding granted in the form of small loans (of 30\% of the per capita gross national income (GNI)) (CERISE, 2011). None of the organizations has funded tourism development projects with financial instruments for an amount of less than $30 \%$ of the per capita GNI. Thus, to establish a reference figure enabling this indicator to provide information, small loans have been defined as those of less than USD 1 million.

Using this new reference, $20 \%$ of the funding for tourism development projects provided by IFIs was for amounts of less than USD 1 million (Table 11). This figure is possible thanks to the OAS, whose funding portfolio is composed of small financial instruments. The remainder of the organizations scarcely use this type of funding instrument.

Indicator D8 reveals the importance attached to non-repayable grants by IFIs to fund tourism in LAC. Guarantees are a very useful financial instrument with low costs. They represent a significant benefit in terms of financial inclusion, since exclusion from the financial system, in most cases, occurs because applicants are considered to be poor risks. The MIGA exists for this purpose. However, the rest of the organizations make no use of this tool, regardless of its utility and the potential of guarantees.

On occasion, IFIs channel the funding for tourism through other financial institutions. This method allows them not only to support the formal financial system by focusing on inclusion, but also to reach a higher number of final beneficiaries. Furthermore, this second consequence is achieved by funding projects that involve other projects in turn.

Figure 5 suggests that the IFC (8.24\%) and the IDB (3.34\%) are the only IFIs that fund tourism development projects through other financial institutions (indicator D10), with a mean value of $2.32 \%$. In the case of funding for tourism through subprojects, IFIs channel $28 \%$ of the funding, demonstrating that they value the potential of funding projects that involve other tourism-related subprojects. 
Table 11. Indicators for the study of the characteristics of the funding, results

\begin{tabular}{|c|c|c|c|c|c|c|}
\hline Indicator & WB & IFC & MIGA & IDB & OAS & TOTAL \\
\hline $\mathrm{D} 1$ & 0.30 & 0.14 & 0.42 & 0.23 & 0.38 & 0.29 \\
\hline D2 & 6.91 & 3.35 & - & 39.17 & - & 16.47 \\
\hline D3 & $0.34 \%$ & - & - & $0.40 \%$ & - & $0.37 \%$ \\
\hline D4 & 254.87 & - & 174.00 & 292.65 & - & 240.50 \\
\hline D5 & 90.52 & - & - & 59.87 & - & 75.20 \\
\hline D6 & $7.47 \%$ & $0.00 \%$ & $0.00 \%$ & $1.93 \%$ & $0.00 \%$ & $1.88 \%$ \\
\hline D7 & $0.00 \%$ & $0.04 \%$ & $0.13 \%$ & $1.48 \%$ & $100.00 \%$ & $20.33 \%$ \\
\hline D8 & $9.04 \%$ & $0.00 \%$ & - & $3.92 \%$ & $100.00 \%$ & $28.24 \%$ \\
\hline D9 & $0.00 \%$ & $0.00 \%$ & $100.00 \%$ & $0.00 \%$ & $0.00 \%$ & $20.00 \%$ \\
\hline D10 & $0.00 \%$ & $8.24 \%$ & $0.00 \%$ & $3.34 \%$ & $0.00 \%$ & $2.32 \%$ \\
\hline D11 & $32.26 \%$ & $18.18 \%$ & $83.33 \%$ & $8.39 \%$ & $0.00 \%$ & $28.43 \%$ \\
\hline
\end{tabular}

Note: Multivariate Pillai test for the standardized values 0.741 and $p$-value $<0.001$.

Table 12. Indicators of non-financial assistance for financial inclusion, results

Source: Authors' own elaboration from WB (2015), IFC (2015), MIGA (2015), IDB (2015) and OAS (2015).

\begin{tabular}{c|c|c|c|c|c|c}
\hline Indicator & WB & IFC & MIGA & IDB & OAS & TOTAL \\
\hline E1 & $25.81 \%$ & $5.45 \%$ & $0.00 \%$ & $15.38 \%$ & $18.18 \%$ \\
E2 & $25.81 \%$ & $1.82 \%$ & $8.30 \%$ & $11.89 \%$ & $18.18 \%$ & $13.00 \%$ \\
\hline
\end{tabular}

Note: Multivariate Pillai test for the standardized values 0.014 and $p$-value 0.121 .

\subsection{Non-financial assistance for financial inclusion}

Funding to promote financial inclusion not only implies support from a financial perspective, but also requires technical support. On average, 13\% (Table 12) of the funding for tourism granted by IFIs has been accompanied by technical assistance and training in financial and business management. Ideally, this type of assistance should be provided in all projects.

As already indicated in section 4.1, for this group of indicators, there are no differences in the evaluations according to the different IFIs.

\section{BREAKDOWN OF THE RESULTS OF THE TOOL TO MEASURE FINANCIAL INCLUSION}

After the tool for measuring financial inclusion efforts has been developed and validated by the panel of experts, this section provides an analysis of the extent to which IFIs implement financial inclusion policies in tourism-related development projects in Latin America and the Caribbean. Their performance in relation to each of the indicators is examined after the standardisation of the data obtained, applying equation 1 to the results.

Applying the formula for standardization given in section 2 to each block of indicators and each organization, standardized values are obtained, allowing the pertinent conclusions to be drawn. After the standardization, the data obtained for each of the indicators are shown in Table 13.

Adding the "positive" standardised results and deducting the "negative" ones for each section and organization (each organization being "I") leads to the following statistical expressions:

$$
\begin{aligned}
& Z_{I . A}=\frac{1}{6} \cdot\left(Z_{I . A 1 a}+Z_{I . A 1 b}+Z_{I . A 2 a}+\right. \\
& \left.+Z_{I . A 2 b}+Z_{I . A 3 a}+Z_{I . A 3 b}\right)
\end{aligned}
$$

$$
\begin{aligned}
& Z_{I . B}=\frac{1}{10} \cdot\left(Z_{I . B 1}+Z_{I . B 2}+Z_{I . B 3}+Z_{I . B 4}+\right. \\
& \left.+Z_{I . B 5}-Z_{I . B 6}+Z_{I . B 7}+Z_{I . B 8}-Z_{I . B 9}+Z_{I . B 10}\right)
\end{aligned}
$$




$$
\begin{aligned}
& Z_{I . C}=\frac{1}{13} \cdot\left(-Z_{I . C 1}-Z_{I . C 2}-Z_{I . C 3}+Z_{I . C 4}+\right. \\
& +Z_{I . C 5}+Z_{I . C 6}-Z_{I . C 7}+Z_{I . C 8}-Z_{I . C 9}+ \\
& \left.+Z_{I . C 10}+Z_{I . C 11}+Z_{I . C 12}+Z_{I . C 13}\right), \\
& Z_{I . D}=\frac{1}{11} \cdot\left(-Z_{I . D 1}-Z_{I . D 2}-Z_{I . D 3}+Z_{I . D 4}+\right. \\
& +Z_{I . D 5}+Z_{I . D 6}-Z_{I . D 7}+Z_{I . D 8}-Z_{I . D 9}+ \\
& \left.+Z_{I . D 10}+Z_{I . D 11}\right), \\
& Z_{I . E}=\frac{Z_{I . E 1}+Z_{I . E 2}}{2} .
\end{aligned}
$$

It is also possible to obtain a total value for the entire tool and for each IFI, which makes it possible to draw general conclusions regarding the average performance of a tourism-funding organization in relation to a given set of indicators, section or the complete tool in terms of financial inclusion. Thus, the expression would be written as follows:

$$
Z_{I}=\frac{Z_{I . A}+Z_{I . B}+Z_{I . C}+Z_{I . D}+Z_{I . E}}{5}
$$

Table 14 lists the average standardized results by section and for the entire tool.

Table 14. Standardized results of the tool, by section and overall

Source: Authors' own elaboration from WB (2015), IFC (2015), MIGA (2015), IDB (2015) and OAS (2015).

\begin{tabular}{l|c:c:c:c:c}
\hline \multicolumn{1}{c}{ Indicators } & WB & IFC & MIGA & IDB & OAS \\
\hline A indicators & 0.45 & 0.25 & -1.40 & 0.10 & 0.56 \\
B indicators & -0.24 & 0.61 & -0.96 & 0.53 & 0.04 \\
C indicators & -0.35 & 0.45 & -0.61 & 0.42 & 0.09 \\
D indicators & 0.29 & 0.20 & 0.01 & -0.32 & -0.15 \\
E indicators & 1.46 & -1.10 & -0.99 & 0.05 & 0.56 \\
Total & 0.32 & 0.08 & -0.79 & 0.15 & 0.22 \\
\hline
\end{tabular}

For the A indicators, which include three indicators that are "positive", the average results suggest that the best-performing organization, that which is more strongly oriented to combating financial exclusion, is the OAS, with an average value of 0.56 . The MIGA, whose tourism projects include

\begin{tabular}{|c|c|c|c|c|c|}
\hline Indicator & WB & IFC & MIGA & IDB & OAS \\
\hline A1.a & 0.09 & 1.67 & -1.47 & -0.07 & -0.22 \\
\hline A1.b & -0.39 & 1.44 & -1.62 & 0.26 & 0.29 \\
\hline A2.a & 1.53 & -0.96 & -0.96 & -0.42 & 0.79 \\
\hline A2.b & 0.71 & -0.79 & -0.79 & -0.76 & 1.62 \\
\hline A3.a & 0.86 & 0.18 & -1.89 & 0.80 & 0.05 \\
\hline A3.b & -0.10 & -0.06 & -1.76 & 1.07 & 0.80 \\
\hline B1 & -0.25 & 0.56 & -1.28 & 1.61 & -0.64 \\
\hline B2 & -0.50 & 2.00 & -0.50 & -0.50 & -0.50 \\
\hline B3 & -0.50 & 2.00 & -0.50 & -0.50 & -0.50 \\
\hline B4 & 0.22 & -0.86 & -1.33 & 0.51 & 1.52 \\
\hline B5 & -0.15 & -0.70 & -1.20 & 0.31 & 1.72 \\
\hline B6 & 1.17 & -1.37 & -0.95 & 0.25 & 0.88 \\
\hline B7 & -0.31 & 0.32 & -1.34 & 1.70 & -0.37 \\
\hline B8 & 0.18 & 0.63 & -1.88 & 1.02 & 0.08 \\
\hline B9 & 0.52 & -0.14 & 1.56 & -0.61 & -1.36 \\
\hline B10 & -0.66 & - & - & -0.76 & 1.41 \\
\hline $\mathrm{C} 1$ & 0.52 & -0.14 & 1.56 & -0.61 & -1.36 \\
\hline $\mathrm{C} 2$ & 1.16 & 0.12 & 0.96 & -0.86 & -1.39 \\
\hline $\mathrm{C} 3$ & 0.65 & 0.01 & 1.47 & -0.83 & -1.30 \\
\hline $\mathrm{C} 4$ & -0.50 & 2.00 & -0.50 & -0.50 & -0.50 \\
\hline C5 & -0.50 & 2.00 & -0.50 & -0.50 & -0.50 \\
\hline $\mathrm{C} 6$ & 1.91 & -0.75 & -0.49 & 0.06 & -0.75 \\
\hline C7 & 0.81 & -1.81 & -0.38 & 0.65 & 0.68 \\
\hline C8 & 0.31 & -1.18 & -1.18 & 1.01 & 1.00 \\
\hline C9 & -0.91 & -0.65 & 0.85 & 1.50 & -0.85 \\
\hline $\mathrm{C} 10$ & -0.50 & 2.00 & -0.50 & -0.50 & -0.50 \\
\hline C11 & -0.50 & 2.00 & -0.50 & -0.50 & -0.50 \\
\hline $\mathrm{C} 12$ & -0.26 & -0.50 & -0.45 & 1.97 & -0.76 \\
\hline C13 & -0.42 & -0.91 & -1.07 & 1.20 & 1.20 \\
\hline D1 & 0.05 & -1.51 & 1.20 & -0.66 & 0.85 \\
\hline D2 & -0.59 & -0.81 & - & 1.41 & - \\
\hline D3 & -1.00 & - & - & 1.00 & - \\
\hline D4 & 0.66 & - & -0.10 & 1.02 & -1.58 \\
\hline D5 & 1.00 & - & - & -1.00 & - \\
\hline D6 & 1.93 & -0.65 & -0.70 & 0.02 & -0.70 \\
\hline D7 & -0.51 & -0.51 & -0.51 & -0.47 & 2.00 \\
\hline D8 & -0.35 & -0.58 & -0.57 & -0.48 & 2.00 \\
\hline D9 & -0.50 & -0.50 & 2.00 & -0.50 & -0.50 \\
\hline D10 & -0.72 & 1.83 & -0.72 & 0.32 & -0.72 \\
\hline D11 & 0.13 & -0.35 & 1.85 & -0.68 & -0.97 \\
\hline E1 & 1.40 & -0.82 & -1.39 & 0.26 & 0.54 \\
\hline E2 & 1.53 & -1.38 & -0.59 & -0.16 & 0.57 \\
\hline
\end{tabular}
very few objectives aimed at financial inclusion, shows exactly the opposite, with its average relative value of the indicators at -1.40 .
Table 13. Standardized results of the tool by indicator

Source: Authors' own elaboration from WB (2015), IFC (2015), MIGA (2015), IDB (2015) and OAS (2015). 
Within the group of $\mathrm{B}$ indicators, the best-performing organization in view of the standardized results obtained for this section is the IFC with a value of 0.61 , followed by the IDB with a value of 0.53 . The case of the MIGA (-0.96) is the opposite.

Section C indicators analyze the volume of funding and tourism development projects and the distribution between recipients. In this case, the IFC again performs better than others in terms of financial inclusion; the average value of the standardized $\mathrm{C}$ indicators is 0.45 , followed by the IDB (0.42), as in the case of the B indicators. Once again, the MIGA performs worst $(-0.61)$ in this regard. Thus, the conclusions of the analysis in the previous section are confirmed.

The WB (0.29) performs best in the section D indicators of the tool, followed by the IFC $(0.20)$. Therefore, the terms offered by the WB and the IFC for the funding of tourism are better suited to address the problem of financial exclusion than those offered by the other organizations. However, this is not entirely true, since these organizations did not provide enough information to obtain reliable results for all indicators. Therefore, it can be argued that none of the organizations stand out for their actions in favor of financial inclusion when establishing the terms and instruments for the funding of tourism development projects.

The final section, the $\mathrm{E}$ indicators, reveals that the WB performs best, with an average value of the indicators far higher than compared with other cases (1.46).

Finally, a ranking can be established based on the total value obtained using this tool, presenting in ascending order the work performed by each organization in the funding of tourism. Thus, the ranking would be as follows:

\section{World Bank (0.32).}

2. Organization of American States (0.22).

3. Inter-American Development Bank (0.15).

4. International Finance Corporation (0.08).

5. Multilateral Investment Guarantee Agency $(-0.79)$.

All organizations, except for the MIGA, show aboveaverage performance, with the $\mathrm{WB}$ results reflecting a more significant contribution to financial inclusion. In the description of the standardized results by section, the most relevant organization was not the WB but rather the IFC. However, the relative performance in section $\mathrm{E}$ has reduced the final average, making it the second lowest in the ranking.

Overall, the IFC is the best organization regarding the work performed in favor of financial inclusion in the funding of tourism. However, non-financial assistance must still be addressed, which undermines the final result.

\section{CONCLUSION}

The tool makes it possible to determine whether the funding granted by IFIs in the field of tourism contributes to financial inclusion, and thereby to ascertain whether the work done through tourism development aligns with IFIs' policies to combat financial exclusion, at least on paper.

This tool has been applied to nearly three hundred projects funded by these organizations in Latin America and the Caribbean since the early 1990s to 2012. The results suggest that the efforts made by IFIs in terms of financial inclusion in Latin America and the Caribbean are far from proportional to the importance placed on combating financial exclusion in its policies. Actually, there is no connection between what IFIs preach in their strategic approach and what they practice in combating financial exclusion in tourism development projects.

In reality, the primary beneficiaries of most tourism-related financing by these organizations are governments and large companies, although this practice does favor financial inclusion. Furthermore, 
they enjoy certain characteristics that are more favourable than normal market conditions, because these recipients have the largest access to financial markets. Therefore, neither the features, nor the volume of the funding, nor the non-financial assistance offered by these organizations promotes financial inclusion.

Based on the standardized value of the tool's results, we rank the organizations' contributions toward inclusion through the funding of tourism in Latin America and the Caribbean. The WB scores the highest value, whereas the MIGA scores the lowest. However, by analyzing the performance in each of the indicators, the IFC performs best in terms of financial inclusion through the funding of tourism.

The final results imply that the funding of tourism by IFIs is not a strategic approach for financial inclusion. This funding is not inclusive from a financial perspective, and thus the effort being made in this regard is not altogether sufficient.

It is therefore essential to begin by raising awareness of the importance of financial inclusion and tourism and their role as instruments of economic development. In addition, a strategic approach must be established to serve as a guide for IFIs to provide inclusive funding for tourism, thereby making them more efficient in achieving their development objectives and reducing poverty.

\section{REFERENCES}

1. AENOR (2003). UNE 66175:2003: Sistemas de gestión de la calidad. Guía para la implantación de sistemas de indicadores. Madrid: AENOR.

2. Argumedo, P. (2017). Inclusión financiera de pequeños productores rurales: estudio de caso en $\mathrm{El}$ Salvador. Documentos de proyectos. Washington, CEPAL.

3. Ashley, C., De Brine, P., Lehr, A., \& Wilde, H. (2007). The Role of the Tourism Sector in Expanding Economic Opportunity. Corporate Social Responsibility Initiative Report. 23. Cambridge: John F. Kennedy School of Government, Harvard University.

4. Botello, H. (2015). Determinantes del acceso al crédito de las PYMES en Colombia. Ensayos de Economía, 25(46), 135. http:// dx.doi.org/10.15446/ede

5. Carrillo-Hidalgo, I., \& PulidoFernández, J. I. (2016). Is the financing of tourism by international financial institutions inclusive? A proposal for measurement. Current Issues in Tourism, 1-27. https://doi.org/10.1080/13683500. 2016.1260529

6. CEPAL (Comisión Económica Para América Latina y El Caribe) (2007). Estudio económico de América Latina y el Caribe 2006-2007. New York: CEPAL, United Nations.

7. CEPAL (Comisión Económica Para América Latina y El Caribe) (2008). Estudio económico de América Latina y el Caribe 2007-2008. New York: CEPAL, United Nations.

8. CEPAL (Comisión Económica Para América Latina y El Caribe) (2009). Estudio económico de América Latina y el Caribe 2008-2009. New York: CEPAL, United Nations.

9. CEPAL (Comisión Económica Para América Latina y El Caribe) (2010). Estudio económico de América Latina y el Caribe 2009-2010. New York: CEPAL, United Nations.

10. CEPAL (Comisión Económica Para América Latina y El Caribe) (2012). Estudio económico de América Latina y el Caribe. Las políticas ante las adversidades de la economía internacional. New York: CEPAL, United Nations.

11. CERISE (2011). SPI Gide v3.3. Paris: CERISE.

12. Chandrasekhar, C. P. (2007). Estrategias nacionales de desarrollo. Guías de orientación de políticas públicas. Políticas financieras. New York: United Nations.
13. Čihák, M., N’Diaye, P., Barajas, A., Mitra, S., Kyobe, A., Mooi, Y. N., \& Yousefi, S. R. (2015). Financial Inclusion: Can It Meet Multiple Macroeconomic Goals? Staff Discussion Notes, 15/17. Washington: International Monetary Fund.

14. Cull, R., Ehrbeck, T., \& Holle, N. (2014). Financial inclusion and development: Recent impact evidence. Focus Note, 92. Washington, CGAP.

15. Demirgüç-Kunt, A., Klapper, L. F., Singer, D., \& Van Oudheusden, P. (2015). The Global Findex database 2014: Measuring financial inclusion around the world (World Bank Policy Research Working Paper No. 7255). Washington: World Bank Group.

16. Demirgüç-Kunt, A., Klapper, L., Singer, D., Ansar, S., and Hess, J. (2018). Measuring financial inclusion: The Global Findex Database. Washington: World Bank Group.

17. Enterprise Surveys (2018). Official web page. Retrieved from http:// www.enterprisesurvey.org/ (accessed on April 30, 2018).

18. FELABAN (Federación Latinoamericana de Bancos) (2016). II Informe de Inclusión Financiera 2016. Bogotá: FELABAN. 
19. Hawkins, D., \& Mann, S. (2007). The World Bank's role in tourism development. Annals of Tourism Research, 34(2), 348-363. https://doi. org/10.1016/j.annals.2006.10.004

20. Hirschman, A. O. (1964). The paternity of an Index. The American Economic Review, 54(5), 761. Retrieved from http://grundrisse. org/copyright_violations/Paternity_of_an_Index.pdf

21. IDB (Interamerican Development Bank) (2015). Official web page. Retrieved from https://www.iadb. org/en (accessed on December 22, 2015).

22. IFC (International Financial Corporation) (2015). Official web page. Retrieved from https:// www.ifc.org/wps/wcm/connect/ corp_ext_content/ifc_external_ corporate_site/home (accessed on December 22, 2015).

23. Jafari, J. (1990). Research and Scholarship: The Basis of Tourism Education. The Journal of Tourism Studies, 1, 33-41. Retrieved from https://www.cabdirect.org/cabdirect/abstract/19901880625

24. Ledgerwood, J. (1999). Sustainable banking with the poor. Microfinance Handbook. An institutional and financial perspective. Washington: The International Bank for Reconstruction and Development.

25. Markandya, A., Taylor, T., \& Pedroso, S. (2005). Tourism and sustainable development: Lessons from recent World Bank experience. Proceedings of Conference on Tourism and Sustainable Economic Development: macro and micro economic issues. Chia (Italy), 19-20.

26. Mehrotra, A., \& Yetman, J. (2015). Inclusión financiera: Implicaciones para los bancos centrales. Boletín, 61(3), 135-150. Retrieved from http://www.cemla.org/PDF/boletin/ PUB_BOL_LXI-03.pdf

27. MIGA (Multilateral Investment Guarantee Agency) (2015). Official web page. Retrieved from http://www.miga.org/ (accessed on December 22, 2015).

28. OAS (Organization for American States) (2015). Official web page. Retrieved from http://www.oas. org/en/ (accessed on December $22,2015)$
29. OECD/INFE (2012). Principios de Alto Nivel de la OCDE/INFE sobre Estrategias Nacionales de Educación Financiera. París: OECD.

30. Perric, J., Mujacevic, E., \& Simunic, M. (2011). International financial institution investments in tourism and hospitality. Journal of International Business and Cultural Studies, 4, 1-17. Retrieved from http://www.aabri.com/manuscripts/10444.pdf

31. Pulido-Fernández, J. I., Flores D., \& Vargas-Machuca, M. J. (2008). Gestión activa de la deuda externa y desarrollo turístico. Los swaps deuda-turismo sostenible. Revista Economía Mundial, 20, 197-227. Retrieved from http:// rabida.uhu.es/dspace/bitstream/ handle/10272/3273/b15326913. pdf? sequence $=1$

32. Ray, D. (2002). Economía del Desarrollo. Barcelona: Antoni Bosch.

33. Roa, M. J. (2014). La inclusión y la estabilidad financieras. Documentos de investigación 15. México, Centro de Estudios Monetarios Latinoamericanos.

34. Roche C. (2004). Evaluación de impacto para agencias de desarrollo. Aprendiendo a valorar el cambio. Barcelona: Intermon Oxfam GB.

35. Rosenberg (2009). Measuring results of microfinance institutions: Minimum indicators that donors and investors should track-A technical guide. Washington: CGAP.

36. Sharpley, R., \& Telfer, D. (2002). Tourism and development: concepts and issues. Clevedon: Channel View Publications.

37. Sinha, F. (2006). Social Rating and Social Performance Reporting in Microfinance Towards a Common Framework. Gurgaon: EDA/MCril, Argidius, y SEEP Network.

38. Stein, P., Randhawa, B., \& Bilandzic, N. (2011). Toward Universal Access Addressing the Global Challenge of Financial Inclusion. Washington: IFC.

39. Tapia, G. (2014). Turismo sostenible. Introducción y marco financiero. Revista de Investigación en Modelos Financieros, 1.

Retrieved from http://ojs.econ.uba. ar/ojs/index.php/RIMF/article/ view/585/1079

40. Trujillo, V., \& Navajas, S. (2015). Inclusión financiera en América latina y el Caribe. Datos y tendencias. Washington: FONIM, Grupo BID.

41. Watewrfield, C. \& Ramsing, N. (1998). Management Information Systems for Microfinance Institutions. A Handbook. Washington: CGAP y WB.

42. WB (World Bank) (2012). Doing Business 2012. Washington: World Bank.

43. WB (World Bank) (2015). Official web page. Retrieved from http:// www.worldbank.org/ (accessed on December 22, 2015).

44. WB (World Bank) (2018). Official web page. Retrieved from http:// www.worldbank.org/ (accessed on May 3, 2018).

45. Xinia, G. (1995). Hacia la elaboración de indicadores de evaluación. Revista Centroamericana de Administración Pública, 28/29, 167-186. Retrieved from http:// publicaciones.icap.ac.cr/images/ PDF-REVISTA/revistadigital64completa.pdf

46. Zuleta, J., \& Alberto, L. (2016). Inclusión financiera de la pequeña y mediana empresa en Colombia. Financiamiento para el desarrollo. Washington: CEPAL. 